\title{
NOTES
}

\section{TAXATION OF SALE AND LEASE-BACK TRANSACTIONS}

ONE of the major policy changes in the Revenue Act of 1950 was the decision, under Title III of the Act, to tax certain rental income of organizations normally exempt under Section 101 of the Internal Revenue Code. Unlike other inroads on tax exemption, ${ }^{1}$ this change was not an attempt to put an end to a departure by Section 101 organizations from traditional fields of charitable and educational financing. The type of investment aimed at-the so-called sale and lease-back ${ }^{2}$-involves dealing in real estate, both as security for a loan, and, after repayment of the loan, as a stable form of incomeproducing property. As the exclusion from other sections of Title III of both interest and rentals indicates, ${ }^{3}$ Congress made no attempt to tax generically the income produced from such dealings. To the extent that any vice was found, therefore, it lay principally not in the source of the income-interest and rentals-but in the tax consequences to the non-exempt parties involved in the transactions.

\section{The Mechanics and the Results}

Despite a spate of publicity during the past five years, ${ }^{4}$ no detailed information is available concerning either the popularity of the sale and lease-back

1. The other two major inroads-taxation of business income, and of the general income of charitable organizations engaging in "prohibited transactions"-are discussed in Comment, Colleges, Charities, and the Revenue Act of 1950, 60 YALE L.J. 851 (1951). The Comment also covers all other changes made by Title III in the treatment of $\S \S 101$ and 162 a organizations.

2. The best coverage of business, tax, and other legal aspects of the sale and leaseback is in Cary, Corporate Financing Throngh the Sale and Lease-Back of Property: Business, Tax, and Policy Considerations, 62 Harv. L. Rev. 1 (1948). See also the articles cited in id. at 1 n.1.

3. The amendment to INr. Rev. Cone $\S 101$, and the addition of $\S \S 422-3$, which were designed to tax business income, explicitly exclude interest and rentals. See Comment, stipra note 1 , at 855 .

4. The Sand Springs Foundation entered into a lease-back transaction with Commander Mills, an Oklahoma textile manufacturer, as early as 1927. Hearings before House Committee on Ways and Means on Revemue Revision of 1950, 81st Cong., 2d Sess. 801 (1950) (hereafter cited as House Hearings). The first widely publicized transaction, however, took place in June 1945, between Union College and Allied Stores, Inc., and involved real estate of a total value of slightly over $\$ 16,000,000$. Of this sum only $\$ 150,000$ was put up by Union, the remainder being furnished by loans to Union from the Guaranty Trust Co. and the Prudential Life Insurance Co. See Cary, supra note 2, at 3-5; Hearings before Senate Committee on Finance on Revenue Revisions of 1950, 81st Cong., 2d Sess., 560-66 (1950) (hereafter cited as Senate Hearings); House Hearings 167. Since then, numerous large retail outlets, including Macy's, Gimbels, 
device, or what precise contractual arrangements are most widely used. The importance of the tax consequences involved is therefore not certain. Nontax business reasons undoubtedly weigh heavily in the decisions to finance new money by this rather than other devices. 5 Taxable real estate firms may already have appeared in lease-back arrangements as potential lenders. ${ }^{6}$ To the extent that the new law diminishes the usefulness of the tax exemption, they will presumably participate more frequently. At present, however, the use of the device is in the main tied to charitable institutional, particularly university, financing. ${ }^{7}$ And it is being used; there is no question here, as there is in the taxation of business income under I. R. C. Section 422, of taxing a ghost. ${ }^{8}$ While the university representatives agreed in principle with the taxation of university-owned spaghetti factories, there was violent and bitter dissent in the Congressional hearings to the proposition that any rental income be in any way touched. ${ }^{9}$

Sears Roebuck and Montgomery Ward have entered into similar deals. See Cary, supra note 2, at $2 \mathrm{n} .4$, and articles cited; Honse Hearings 801 ; Hearings before House Committee on Ways and Means on Revenne Revisions 1947-48, 80th Cong., 1st Sess. 3437-3553 (1948); Mezerik, The Foundation Racket, New Republic, p. 11, January 30, 1950.

5. See Cary, supra note 2, at 5-16. Charles Foster Brown, counsel for Union College, indicated in a statement presented before the Senate Finance Committee that the principal reasons for Allied's participation in the Allied-Union transaction were purely business non-tax reasons. Senate Hearings 557. See also testimony of Paul C. Cabot, Treasurer of Harvard, House Hearings at 496.

6. See Century Electric Co., 15 T.C. 581, 586 (1950) (overtures from real estate firms suggesting sale of foundry with an immediate lease-back; the reference in the opinion does not make clear whether the firms were to be only intermediaries or actually the vendee-lessor); cf. Cary, supra note 2, at 30 ("Obviously, only a tax-exempt institution . . . could be economically introduced as title-holder.").

Cary's statement appears too categorical. Real estate investors are continually buying realty and leasing it to someone. There is no economic reason why they could not lease it back to the vendor. Presumably all Cary means is that it would normally be cheaper for the vendor to deal with a $\$ 101$ organization.

7. In addition to Union College, various lease-back transactions have been entered by Chicago, Oberlin, Pennsylvania and Yale, among others. See House Hearings 801 for a sampling of terms. Non-university Section 101(6) vendee-lessors have included the Rayon Foundation Trust, the Lansing Trust, the Rhode Island Charities Trust and the Sixty Trust. Ibid. The transactions involved were with various textile manufacturers, including Textron, Inc. Cf. Comment, The Modern Philanthropic Foundation: A Critique and a Proposal, 59 Y ALE L.J. 477, 492-7; Honse Hearings 510-30.

8. See Comment, supra note 1 , at 856.

9. Compare the statements of Harold E. Stassen, President of the University of Pennsylvania, disapproving university-owned business enterprise, Senate Hearings 502 et seq., especially 511-13, with the action of the University of Pennsylvania in participating in a debt-financed sale and lease-back, and its defense thereof, House Hearings 574 et seq. See also testimony of Dr. Carter Davidson, President of Union College and Chairman of the Committee on Taxation of the American Council on Education, in Senate Fearings 527; testimony of Paul C. Cabot, Treasurer of Harvard, House Hearings 495. 
The Mechanics of the Device. In its simplest form, the sale and lease-back involves one method whereby a taxable business, $\mathrm{X}$, can borrow money from, or through, a tax-exempt institution, typically a university, $\mathrm{Y} . \mathrm{X}$ holds, for example, real estate consisting of $\$ 5,000,000$ worth of land, and buildings of $\$ 5,000,000$ net depreciated value. This real estate is sold to $Y$ for its full value. ${ }^{10}$ As a condition of the sale, $Y$ immediately leases the property back to $\mathrm{X}$ on a long-term basis, usually with an option to renew at a fair rental to be computed at the time of the renewal, sometimes with an option to purchase. ${ }^{11}$ The "rental" for the first period of the lease is sufficient to return to $Y$ the purchase price plus a rate of interest usually somewhat higher than the normal going rate. Payments are fixed on a decreasing scale, as in the case of a mortgage. ${ }^{12}$ Liability for taxes, insurance and other maintenance costs and ground rents, if any, is on the lessee.

The major variation in this type of deal occurs when $Y$ either cannot, or does not wish to, participate without borrowing all or part of the purchase price. This situation results in bringing two more parties into the transaction- $Z$, a wholly owned subsidiary of $Y$, and $A$, an institutional investor. $Z$ now takes the part of the buyer-lessor, and adds to whatever cash $Y$ supplies a sum raised

10. This was done in the Allied Stores transaction. See Cary, supra note 2, at 3 . It is sometimes suggested that the original "sale" price may be fixed low in order to permit the taking of a capital loss under $\$ 117(\mathrm{j})$. INT. Rev. CodE $\$ 117(\mathrm{j})$. See Blodgett, Taxation of Business Conducted by Charitable Organizations, NEw YORK UNTVESITY FOURTH Annual Institute on Federal Taxation 418, 433 (1946). It is true that a sale and lease-back may not always be an arms-length transaction. See, e.g., Central Electric Co., 15 T. C. 581,590 (1950) (president of the vendor-lessee company also a trustee of William Jewell College, the vendee-lessor, which was in turn a stockholder in the company). But if cash is what is desired, as is the usual case, setting a deliberately low price in order to take a capital loss seems extremely uneconomic behaviour. For discussion of the legal dangers involved, see note 25 infra.

11. If an option to purchase is used, the danger of having the whole transaction treated tax-wise as a mortgage is greatly increased. See cases cited in notes 58 and 59 infra. This danger has probably in effect eliminated use of that form of lease. Cf. testimony of Dr. J. R. Killian, Jr., President of the Massachusetts Institute of Technology, House Hearings 502.

12. In the Allied Stores transaction, the leases provided for an original term of 30 years, during which the purchase price would be repaid in annual diminishing "rentals," plus a net return of about $3 \frac{\mathrm{r}}{2} \%$. See Cary, supra note 2 , at 4 . Shortly after entering the leases Allied was able to borrow $\$ 25,000,000$ from insurance companies at a rate of $3 \mathrm{r} / 8 \%$. $I d$. at 9. Cary gives three reasons for the differential between the normal credit rate and that obtained in lease-back transactions: (1) lack of creditor status on the part of the vendee-lessor; (2) less liquidity in the investment; and (3) the time, trouble and expense involved in fixing the lease and sale terms. Id. at 9-11. Each of these seems a possible contributory factor, but their combined weight seems inadequate as a full explanation. A possible fourth reason may be that the vendor-lessee is simply, despite the higher interest rate, getting an overall cheaper money supply, because of the tax saving involved, than he could by other means. Cf. House Hearings 558 . 
by a loan from A. ${ }^{13}$ The loan is evidenced by bonds, issued by $Z$ and secured by the property purchased. The property is then assigned to $Y$, subject to the mortgage, and to the terms of the trust indenture. The debt to A, plus interest, is paid off out of the "rentals." The interest rate charged is typically the going interest rate, slightly below that charged by $\mathrm{Y}$ to $\mathrm{X}$, so that some return to $\mathrm{Y}$ is realized even during the period of the mortgage. $\mathrm{Y}$ is, in this type of transaction, little more than an intermediary dummy between the real borrower, $\mathrm{X}$, and the real lender, $\mathrm{A} .{ }^{14}$

The advantages to $Y$ in either hypothetical are apparent. Particularly in an era of continuing inflation, a university is likely to follow a policy of investing heavily in real estate, whose stability in relative value makes an excellent hedge against losses arising from currency fluctuations. As a matter of policy, a university will not normally carry much common stock in its portfolio. ${ }^{15}$ Real estate is a substitute counter-inflationary investment. The sale and lease-back device offers a method whereby the money invested in realty may be doing double duty-i.e., earning interest at the same time that it is paying for the property. ${ }^{10}$ In addition, the vendee-lessor makes an otherwise favorable investment whether it is the principal or an intermediary in the transaction.

13. The function of the subsidiary is not entirely clear. Cary suggests that is is designed to achieve limited liability on the part of the university involved. Cary, supra note 2 , at 38. The idea seems to be an equation of a real estate holding subsidiary with one running a business. While the desire for limited liability is undoubtedly strong in the latter case, see Comment, supra note 1 , at 861 , it is probably of minor or no importance when realty is involved. The university often makes no attempt to limit its liability, but assumes through a supplementary trust indenture full responsibility for its subsidiary's debt. A more likely explanation is that the subsidiary is simply a means of implementing a university policy not to appear as a mortgagor on the books of the institutional investor, A university wholly-owned subsidiary is apt to be in the constantly strained financial position of having no assets, but large debts. Obviously, the holders of its bonds are looking through it to the university for security status.

14. See pages $890-91$ infra.

15. Cf. the editorial Tax Reckoning is Coning!, Christian Century, Nov. 30, 1949, reprinted in House Hearings 811-13. Some universities are probably slowly forsaking this policy.

16. For example, a piece of real estate purchased for $\$ 10,000$ may be optimistically expected to return the investment over a period of ten years, i.e. yield rentals of $\$ 1,000$ a year. Compare this investment with an equally reasonable sale and lease-back arranged so as to return the loan over a ten-year period. There the vendee-lessor not only gets the $\$ 10,000$ back in the ten-year period, but also receives $3 \frac{\pi}{2}$ to $33 / 4 \%$ on it during the same time.

The possibility of this type of additional gain is especially clear with university bookkeeping methods. It is common university practice to apply the proceeds from an investment in land to amortization of the price paid for it. In the lease-back transaction, this is done automatically. On top of that, there are interest payments corresponding to what would be realized if the purchase price of the property were simultaneously invested in high interest bonds. This can be treated as free income during the original term of the lease while the purchase price is being written off. Thereafter the total rental payments can be considered clear income. 
Where a university puts up the purchase price itself, it gains a more favorable yield than other investments of similar security afford. Where it borrows to put up the money, it is able to make an immediate small profit on the differential between the rate paid it and the rate paid by it, and ultimately to gain clear title to a valuable piece of property at the risk of a minimal investment.

The advantages to the vendor-lessee are not so clear. He is in the seemingly strange position of paying a higher rate of interest to enter a transaction whereby he ultimately loses his title in real property which, if not desirable as an income-producing capital asset, would at least ultimately become available again as security for future financing after the payment of a present mortgage. His alternative would be a mortgage requiring lower interest rates, ${ }^{17}$ and affording an opportunity for both junior financing and refunding of the original debt. The reasons-both tax and business-for choice of the lease-back device must, in the face of its disadvantages, be strong. It seems probable that present popularity is at least in part a fad, that tax advantages are to some extent ephemeral, and other features debatable.

The Non-Tax Consequences. The usual justification for use of the leaseback device is that it enables the vendor-lessee to raise more money than by other forms of financing, more simply, and without deleterious effect on credit standing or restrictions on future borrowing. ${ }^{18}$ Large retail firms first brought popularity to the device, and are still its most publicized users. For them, investment in real estate meant, in the post-war boom, loss of the potential profit to be gained from investment in inventory. Rapidly soaring prices put a premium on fast turnover; a million dollars invested in inventory could yield ten per cent several times a year, while the same amount invested in real estate did no more than save rental payments which anyway were deductible tax items. ${ }^{19}$ What was needed was cash, not fixed assets.

The lease-back apparently fitted neatly into the picture. Whereas a mortgage can normally be used to raise money to the extent of no more than threequarters or four-fifths of the value of the property involved, a lease-back, like a mortgage, permits retention of the use of the property, yet raises cash to its

17. See note 12 supra. The usual differential has been variously reported as ranging from $3 \% \%$, Cary, supra note 2 , at 27 , to $1 \%$, House Hearings 558 (testimony of King E. Fauver, counsel to Oberlin College).

18. The advantages "include unimpaired credit, long-term commitment, nonacceleration of rent on defauit as against acceleration of loans on default, and an opportunity to reduce or eliminate the rent commitment in bankruptcy or reorganization proceedings." House Hearings 558. The whole range of non-tax advantages are discussed in some detail and with much sense in Cary, supra note 2, at 5-16, 39-40.

19. See quotations in Cary, supra note 2 , at 13 n.29. In a way, this trend is beneficial rather than detrimental to Government revenue. To the extent that use of the lease-back device promotes a larger turnover of inventory it thereby creates higher income and higher taxes on the business. In situations where the lease-back is the only practicable way of raising quick cash, therefore, the revenue loss complained of is nonexistent in fact. 
full value. ${ }^{20}$ Since it is not in form a credit transaction, it avoids restrictions imposed by previous creditors, and itself imposes no new ones. ${ }^{21}$ The balance sheet is clean; within limitations set by SEC rules ${ }^{22}$ and general accounting practice, ${ }^{23}$ no report need be made of the transaction, and no record of it left for the perusal of potential future creditors. In effect, the lease-back permits a business to borrow without becoming a debtor, and the adverse results of the debtor status are avoided.

These advantages may often be overrated, and in some instances nugatory. A potential creditor looks not merely at the debt burden of a borrower, but also at all fixed charges, including rents. The careful investor will discover the existence of leases, simply because he will want to know, for example, how many stores a retail chain operates, where they are located, and what their volume is. From the security point of view, while it is true that the vendeelessor does not appear as, and in fact is not, a debtor for purposes of bankruptcy or Chapter $X$ reorganizations, ${ }^{24}$ it is also true that the value of the property involved, as a fixed item, has disappeared from the books. Such deterrents to new financing may overbalance the effect of ending up with a clean balance sheet. To the extent that they do, valid business non-tax reasons for use of the lease-back device are limited to three specific situations: (1) where the funds needed are greater than can be raised by a mortgage, and the additional amount needed cannot be raised by other means; $(2)$ where restrictions on future credit were imposed by prior security transactions; and (3) where the amount needed can otherwise be obtained only at the cost of submission to undesirable restriction on future financing.

The Tax Consequences. Particularly where none of these conditions exists, and probably even where one or more do, the decisive push towards use of the lease-back comes from the attractiveness of certain tax results. The most im-

20. In some instances, the investor is legally limited to a certain percentage of the value of the property used as security. See N. Y. INs. LAw $\$ 81(6)$; Cary, supra note 2, at 7. And even where there are no legal limitations, traditional trust in the constant value of realty has rigidified institutional business practice to a point of sometimes even stricter requirements. Ibid.

Where a particular piece of real estate is not essential to. the conduct of a business, of course, exactly the same tax and business consequences can be achieved by the sale of that property followed by the lease of another and similar piece. Apparently no objections have been raised to such transactions.

21. See discussion in Cary, supra note 2, at 14-16.

22. See SEC Reg. S-X, Rule 12.16 note 5 (1950), requiring balance sheet notation of rentals due on leases extending for periods of three years or more after the date of the balance sheet. Cf. INT. REv. CoDE $\S 423(a)$, designating five years as the relevant period. See Cary, supra note 2, at 11.

23. See Accounting Research Bull. No. 38, issued by the American Institute of Accountants, discussed in Accounting Trends and Technigues 84 (4th Annual Cum. Survey 1950).

24. Depending on the statute under which the debtor is taken, the vendee-lessor would have a claim for varying amounts of future rentals. See Cary, supra note 2 , at 8. 
portant of these is the treatment of payments over the first period of the lease as "rents" rather than amortization plus interest. ${ }^{25}$ As such, they are business expenses, and constitute deductible items for tax purposes. ${ }^{26}$ In effect, repayments on the principal of a debt may thus be deducted from the gross income for the year in which paid.

The complicating factor in this picture is the loss, to the vendor-lessee, of the deductions for depreciation. When title to the property passes, the right to deduct depreciation passes with it to the vendee-lessor, who is normally taxexempt anyway. ${ }^{27}$ In a situation where the property is completely depreciable, where the selling price corresponds precisely to its depreciated net value, and where the original term of the lease is fixed at the expected life of the property, the vendor-lessee has gained a Pyrrhic victory over the tax collector-what he gains by deduction of repayments of principal, he loses by relinquishment of depreciation deductions.

Normally, however, there will be a discrepancy between the "rental" payments and the depreciation deductions which would have been allowed if there had been no "sale." In the first place, in most transactions, some of the property involved is likely to be land, or otherwise non-depreciable. ${ }^{28}$ Secondly, the value of the property at the time of the sale may be substantially higher than the depreciated value, so that the rental deductions corresponding to the depreciation allowance would reflect the current inflationary trend without regard to the historical cost basis required by the Internal Revenue Code. ${ }^{20}$ And

25. A second tax consequence may be the ability to take a capital loss. Since this aspect of the lease-back device is in no way affected by the 1950 revenue revisions, it need not be discussed in detail here. For a thorough discussion of the dangers involved in attempting to claim a capital loss, see Cary, supra note 2, at 21-27. Since the Cary article was written, the Tax Court has disallowed the taking of such a loss where the lease covered a period of more than thirty years, on the grounds that there was simply an exchange solely in kind under INT. REv. CoDE $\$ 112(\mathrm{~b})(1)$ and the 30-year lease provision of U. S. Treas. Reg. 111, §29.112(b)(1)-1 (1943). Century Electric Co., 15 T.C. 581 (1950). The opposite result was reached when the lease was for a period of only 25 years. Standard Envelope Mfg. Co., 15 T.C. 41 (1950).

26. INT. REv. Cone $\$ 23(a)(1)$ (A) is specifically interpreted in U.S. Treas. Reg. 111, $\$ 29.23$ (a)-1 (1943) to apply to "rental for the use of business property." It may be assumed that all the property involved in lease-back transactions is business property.

27. Depreciation deductions are allowable under INT. REv. CoDE §23(1). Only the owner of the fee (i.e., the title holder, the holder of a life estate, or the beneficiary of a trust) is entitled to the deduction. U.S. Treas. Reg. 111, $\$ 29.23$ (1) -1 (1943). This excludes a lessee. Cf. Helvering v. Lazarus \& Co., 308 U.S. 252 (1939).

The interest payments would be deductible, whether the mortgage or lease-back form of credit transaction was used, under $\S 23(\mathrm{~b})$.

28. See U.S. Treas. Reg. 111, $\$ 29.23(1)-(2)$ (1943).

29. Under $\S 114$, the basis for depreciation is the same as that used under $\S 113$ (b) for the purpose of determining capital gain or loss. $\S 113(\mathrm{~b})$ in turn refers back to $\S 113(\mathrm{a})$, which provides that the basis of property "shall be the cost of such property" with certain exceptions not here relevant. 
finally, in any case, the period over which the purchase price is repaid can be manipulated so as to achieve the effect of accelerating the rate of depreciation. ${ }^{30}$

The actual tax advantage to be gained from these factors, of course, involves the prediction that a greater total saving will be made by taking a larger total of deductions during a few years than a smaller amount spread over a longer period of time. For example, in the hypothetical set out above, $X$, the vendor-lessee, would be able to deduct an average of $\$ 500,000$ a year for, say, twenty years (assuming an original lease of twenty years), rather than $\$ 100,000$ a year for fifty years (assuming a life expectancy of fifty more years for the buildings involved). The $\$ 500,000$ per year of current deductions may cancel out the excess profits tax, and correspond with a period of high income and high taxes. Particularly if the period following the original twenty years is a period of low income and low taxes, the lack of any deductions during those years will be more than compensated for by prior savings. Precisely contrary tax and income trends could, however, result in long-range tax disadvantages, so that the savings made in the first period would be less than the amount paid out in higher taxes over the subsequent thirty years.

\section{The Legislative Response}

In this situation Congress saw three major objections. ${ }^{31}$ All of these relate not so much to the fact that different tax results flowed from different forms of credit transactions, as to the part played by the Section 101 organizations involved. The resultant attack was thus not on the lease-back itself, nor on the part played by the vendor-lessee in it, but on the tax exemption which both House and Senate felt made the device possible, and, in some circumstances, dangerous and objectionable.

In the first place, the charitable vendee-lessor seemed to be "selling" or "trading on" its exemption in situations where its own investment was minimal. ${ }^{32}$ If the university put up almost no money of its own, it was in

30. The depreciation is to be figured "over the useful life of the property." U.S. Treas. Reg. $111, \$ 29.23(1)-5$. The useful life of a new store would be around fifty years. Depending on the terms of the transaction, the vendor-lessee can, through a lease-back, decrease the period of writing such a store off from 50 to 30 or 25 years (the original term of the lease) by taking his allowance in "rental" rather than depreciation deductions.

Such acceleration is considered particularly desirable in a period of excess profits tax. It may now legally be obtained for defense industries through a Government-issued certificate of necessity. See, e.g., the report on the new $\$ 115,000,000$ project of Kaiser Aluminum in the N.Y.Times, Jan. 26, 1951, p. 1, col. 4; p. 12, col. 4.

31. See H.R. Rep. No. 2119, 81st Cong., 2d Sess. $38-40$ (1950) (hereafter cited as House REPORT); SEN REP. No. 2375, 81st Cong., 2d Sess. 31-33 (1950) (hereafter cited as SENATE REPORT).

32. "[T] he tax-exempt organization is not merely [when borrowed funds are used] trying to find a means of investing its own funds at an adequate rate of return but is obviously trading on its exemption, since the only contribution it makes to the sale and lease is its tax exemption." SENATe Report 31. Identical language is used in the HOUSE REPORT 38. 
effect contributing nothing but its tax-free status to the transaction. The price paid for that contributon was the differential between normal and lease-back interest rates, plus the right, at some time in the future, to receive income from the property involved.

In the second place, the ability of tax-exempt investors to acquire real estate at the risk of a very small cash outlay was felt to constitute a potential threat to the national economy. ${ }^{33}$ If, as in the widely publicized Allied StoresUnion College transaction, ${ }^{34}$ a university could acquire title to a sixteen million dollar property through an investment of only $\$ 150,000$, the future for taxable real estate investors looked black. Ultimately, tax-exempt institutions might own all the realty in the nation, with a resultant severe drop in federal tax revenues.

Thirdly, Congress felt that somehow the Section 101 vendee-lessor has "sold" its tax exemption in a lease-back transaction, either by paying a higher price or charging a lower rental than a taxable business could afford. ${ }^{35}$ Although this idea is not completely clear in the Congressional reports, it seems to be tied to the "unfair competition" concept discussed with relation to Section 101 organizations' business activity. ${ }^{36}$ If it merely means that tax-exempt organizations can, because of their tax exemption, participate in deals where taxable business cannot, the idea seems no different from that of "trading" on an exemption. On the other hand, the resoning may be based on the double tacit assumption that it would be economically possible for taxable investors to participate as vendee-lessors in lease-back transactions, ${ }^{37}$ and that although Section 101 investment is not sufficiently important in the credit market as a whole to affect the price of money, the tax exemption does give control over the rate of return in the narrower lease-back market. Taxexempt institutions may then be cutting taxable businesses out of that market by setting rates which, because of the taxation of the repayment of principal as "rentals," the taxable investor is unable to afford.

Congress limited these three vices to situations where a lease-back is not financed completely by the Section 101 vendee-lessor. The limitation is valid only as a matter of degree. There is as much of a "sale" of, or "trading" on, the tax exemption, for example, where a university puts up all the money as where it puts up none. As a direct result of any tax saving to the vendor-

33. Ibid.

34. See note 4 supra.

35. Senate Report 31-32; House Report 39.

36. See Comment, supra note 1, at 853-54. Mr. Stassen was at least at one time of the opinion that the business enterprise might gain an unfair advantage over its rivals. See article by Benjamin Fine, N.Y. Times, Jan. 12, 1950, reprinted in House Hearings 587-8.

37. The reports do say that vendor-lessees did not seem to believe that participation by taxable business was possible. House Report 39; Senate Report 32. 
lessee, there would be higher taxes assessed against a taxable vendee-lessor. ${ }^{38}$ These he would be forced to make up by charging a higher interest rate in order to realize as great a return after taxes as he could by other forms of credit investments. The tax-exempt investor has no such problem. The difference between the price he charges and that which a taxable business would have to charge is attributable solely to a "sale" of his exemption, in return for which the vendor-lessee agrees to enter the transaction, yield title to the property, and ultimately cede to the investor the right to a clear income from it. By the same token, the Section 101 organization therefore has a competitive advantage, which could be termed "unfair," over the taxable investor, and is thereby helped along the road to a potential real estate monopoly.

The legislative response, nevertheless, was to limit its action to debtfinanced transactions. ${ }^{39}$ The result is a statute which makes no attempt to interfere with the use of the sale and lease-back as such.40 The target is the Section 101 organization which borrows in order to finance its dealings in realty. The Congressional weapon is a shotgun rather than a rifle-in order to hit all debt-financed lease-backs, Congress used a pattern sufficiently wide to hit all long-term leases of land acquired by or with a debt. The new law is hence both broader and narrower than it might be; lease-backs proper may escape unscathed, while rentals from alumni gifts may be taxed.

The Imposition of the Tax. The operative section imposing taxation on certain rental income of Section 101 organizations is Section 423, which specifies what rentals are to be considered "unrelated business income" for purposes of Sections 422 and 421. The Section 101 organizations affected are hence the same as those affected by the provisions of Section $422 . .^{41}$ Despite their often large land holdings, therefore, churches are specifically exempted. ${ }^{42}$ Although this exemption presumably does not extend to churchsupported schools and universities, they too can probably avoid the tax by the expedient of having realty held in the name of the supporting church, rather than that of the educational institution.

38. The rental payments would constitute taxable income under $\$ 22(\mathrm{a})$. If a leaseback is equated to a mortgage, this would be similar to taxation of the repayments of principal as well as the payment of interest.

39. Senate Report 32; House Report 39.

40. "The tax would apply both to cases where the vendor and the lessee are the same person and those where they are not. Hence, the tax will apply in cases which do not conform strictly with the lease-back plan, but which raise the same problem of unfair competition which the lease-back itself produces ..." House REPORT 39-40. No further explanation is anywhere given for the taxation of rentals from any land aflicted with a debt.

41. For discussion of precisely what types of organizations, generally those under $\S \S 101(1),(6)$ and (7), are covered, see Comment, supra note 1, at 857-59.

42. Some objection was raised to this by university representatives. Senate Hearings 510 (Harold E. Stassen); 526 (Carter Davidson of Union College). Cf. id. at 567 (Stuart Hedden of Wesleyan College). 
Rentals to which the tax applies are those from leases of more than five years in duration on which there is a "Supplement $U$ lease indebtedness." 43 To avoid any attempts at avoidance of taxation by the use of leases of, say, successive periods of four years coupled with options to renew, the section specifically requires that computation of the term of any lease include the periods for which options may be exercised. ${ }^{44}$ Two exceptions to this broad coverage were made by the Senate. First, the section will not apply to leases entered into for purposes "substantially related" to the basis for the exemption of the organization involved, or to leases of premises "primarily designed for occupancy and occupied by the organization." The purposes test will involve the same criteria as those used in determining, under Section $422(\mathrm{~b})$, what business is unrelated in conduct to charitable purposes. ${ }^{45}$ The occupancy clause is designed to permit a hospital, for example, to rent space to a clinic. The second Senate exception makes explicit the treatment of multiple leases on a property ; the section is to apply only if the Supplement $U$ leases cover at least $50 \%$, or any single lease at least $10 \%$, of either the space rented or the income derived from the property. 46

The "Supplement U lease indebtedness" prerequisite to taxation is defined in Section 423(b) to mean the unpaid amount of any indebtedness assumed because of either the acquisition of realty or its improvement. ${ }^{47}$ This includes the amount of a prior existing mortgage to which the property may be subject. Since the tax is to be applied to rentals from property with respect to which there is any such indebtedness at the end of the first taxable year beginning after December 31, 1950, the Section 101 organizations affected have until the end of 1951, or, for those on a fiscal year basis, until June 1952, to pay off their debts or get rid of the property. 48 The obvious advantage this gives large universities with ample free funds over small colleges with little ready cash ${ }^{49}$ is unrelieved by any escape clause. The only exception contemplated is another Senate addition, designed to prevent taxation of rentals from realty

43. $\$ 423(a)$. The Senate changed this from "five years or more" in order to exempt five-year leases. Senate Report 32.

44. Ibid. Cf. U.S. Treas. Reg. 111, §112(b) (1)-1.

45. SENATE REPORT 32. The example there given is the hospital-clinic arrangement. See discussion in Comment, supra note 1 , at 856 .

46. Id. at 33. The Senate felt that there was no attempt to "trade" on the tax exemption where most of the property is rented out on a short-term basis, or where such long-term leases as do exist are spread out among many people.

47. The word "improving" is used several times in the section. Its interpretation will presumably depend on a distinction between repairs and capital expenditures. Compare Reg. 111, $\$ 29.23$ (a) -4 with Reg. 111, $\$ 29.24-2$. This involves such considerations as whether the work is of a recurring nature, its ultimate advantage to the taxpayer, etc. See, e.g., 4 Mertens, Law of Federal Income Taxation $\$ 25.17$ (1942).

48. Since not all mortgages permit acceleration at the option of the mortgagor, this may not be possible in all cases. See House Hearings 557 (offer by Oberlin College to pay off a mortgage refused).

49. For protest against this, see Senate Hearings 562. 
given or devised under debt prior to July 1, 1950, i.e., acquired without any volition having been exercised by the present owner. ${ }^{50}$

Because it is the indebtedness, not the form of the transaction, which is considered important, the tax will be imposed only on that proportion of the rentals which corresponds to the proportion that the amount of the indebtedness bears to the adjusted basis of the property at the close of the taxable year. ${ }^{51}$ Deductions for taxes and other expenses, interest and depreciation will be allowed on the same pro rata basis. ${ }^{52}$ For example, if rentals of $\$ 200,000$ are collected from premises with an adjusted basis of $\$ 2,000,000$, on which there is an unpaid mortgage of $\$ 1,000,000$, the gross taxable income would amount to one-half of $\$ 200,000$, or $\$ 100,000$. Similarly, assuming total expenses, interest and depreciation of $\$ 150,000$ per year, the allowable deductions would come to one-half of that, or $\$ 75,000$, despite the fact that theoretically the whole of the interest payments should be allocable to that half of the rentals which corresponds to the debt.

The major problems raised by this scheme of taxation lie in its attempt to tie the tax to indebtedness incurred for the purpose of acquisition or improvement of property. ${ }^{53}$ Congress was faced with the task of eliminating all attempts at evasion by use of third party intermediaries, subsidiary organizations and substitute security devices. To achieve this end, the statute sets up three tests for identifying Supplement U lease indebtedness: (1) indebtedness incurred by the lessor in acquiring or improving the property; (2) that incurred prior to the acquisition or improvement, if it would not have been incurred "but for" such acquisition or improvement; and (3) that incurred subsequently, if it was reasonably foreseeable at the time of the sale, and would not have been incurred "but for" the acquisition or improvement of the property. ${ }^{54}$ In addition, whenever realty is acquired subject to a mortgage, the indebtedness represented by the mortgage is conclusively presumed

50. The Senate carefully spelled out in its addition to $\$ 423(\mathrm{~b})$ three exceptions based on this theme: (1) realty acquired by gift, bequest, or devise before July 1, 1950 , subject to a mortgage; (2) the same subject to a lease requiring improvements by the lessor (since the university did not put itself in the position of having to make the improvements, it will not be forced to pay taxes if it borrows to make them); (3) indebtedness arising through operation of situations such as are described in clauses 1 and 2 , in the case of a $\$ 101(14)$ corporation, all of whose stock was acquired prior to July 1950, and one-third of whose stock was acquired by gift, bequest or devise.

51. INT. Rev. CODE $\$ 423$ (d).

52. These deductions presumably include all that would be allowed under $\$ 23$ (a) to other taxpayers.

53. The section applies only to real property, unless, under $\$ 423(\mathrm{c})$, personal property is leased "under, or in connection with, the lease of such real estate." A possible explanation for the general exclusion of personal property is that it would normally be fully depreciable anyway, so that the tax saving to the lessee would be minor. No sale and lease-back transactions of personal property have been reported. Compare the problems discussed in Note, The Gift and Leaseback: A New Tax Avoidance Gimmick, 59 YaLE L.J. 1529 (1950).

54. INT. Rev. CODE $\$ 423(\mathrm{~b})$. 
to be Supplement U indebtedness, even if not legally assumed by the lessor, and regardless of whether the property was acquired by purchase, gift or devise.

The first of these tests is designed simply to cover the normal situation where the vendee puts up the property as security for the money he borrowed in order to buy it. The next two provide for the possibility of an intentional time lag. For example, the vendee might mortgage Blackacre in order to raise cash, and six months later buy Whiteacre with the cash thus raised. If Blackacre were a recent acquisition, this would raise the double question of whether the - mortgage on it satisfies the "but for" clause in test number three, and whether the short time interval between that mortgage and the acquisition of Whiteacre satisfies test number 2 so as to make the Whiteacre rentals subject to taxation. Similar fact questions in application of the "but for" and "reasonably foreseeable" tests will necessarily arise if a Section 101 organization adopts a consistent policy of borrowing on personalty or unleased realty in order to keep a supply of cash in readiness for lease-back or other transactions involving rental income.

The presumption to be applied in the case of realty acquired subject to a mortgage negatives most potential problems arising from the use of subsidiaries. No question will be raised by the typical transaction in which a wholly-owned subsidiary borrows cash on the property purchased, and then assigns the property, subject to the mortgage, to the parent university. The rentals clearly will be taxed. Some confusion may arise, however, from the inclusion of the phrase "by the lessor" in test number one. It is not clear whether the phrase is to be read into tests number two and three. If it is to be so read, the following possibility arises: University $\mathrm{Y}$ desires to enter into a lease-back, but has not the cash to do so. In order to raise the cash, Y's subsidiary, $Z$, mortgages personalty, unleased realty, or realty which has been held sufficiently long so that the "reasonably foreseeable" clause in test number three would not apply. $Z$ then buys the property, and assigns it to $Y$. Y leases to the vendor and collects the rents. No indebtedness has then been incurred by the lessor at any time.

\section{A Possible Alternative}

The Supplement $U$ taxation of rentals from debt-financed realty holdings seems in some respects ill-advised. While it may accomplish its purposes of eliminating the use of Section 101 organizations as intermediaries in lease-back transactions, it will necessarily create confusion and some hardship in the process. ${ }^{55}$ Despite lack of any objection to investment by charitable and educa-

55. Union College, for example, probably has not sufficient funds available to pay off its debts on the Allied Stores lands, and may be unable to pay the taxes which will fall due during the next taxable year. The tax will, of course, be in fact confiscatory. Where its actual income is limited to the slight differential in interest paid out by it 
tional institutions in realty subject to a mortgage, this frequent type of transaction will be discouraged even when no lease-back is involved. Borrowing to purchase land is similarly hit by indirection, regardless of lack of tax avoidance, as are rentals from mortgaged land acquired by gift or devise. This is use of a bear trap to catch a mouse.

On the other hand, the purpose of the taxation seems unnecessarily narrow. The fundamental objection to use of the lease-back device should be that it permits different tax results to flow from a variation in the form of a credit transaction. ${ }^{56}$ This factor was ignored by Congressional policy-makers except in so far as it is implied in the "selling" and "trading on the exemption" language used in Committee reports. As pointed out above, the evils denoted by that language are not intrinsically limited to debt-financed transactions. The new law still permits tax-exempt organizations largely to monopolize, because of their tax exemption, a lucrative form of investment. And it still leaves open to taxable business a method of sometimes large-scale tax-avoidance. This is use of a mouse trap to catch a bear.

A possible alternative, apparently never fully considered by Congress, ${ }^{57}$ would be to throw the tax burden back on the vendor-lessee, who is after all the beneficiary of any tax savings realized. Courts have shown themselves willing, in the tax as well as other fields, to treat a deed, absolute in form, as a mortgage. ${ }^{58}$ Similarly, "lease" agreements have been treated as sales, with both interest and depreciation deductions allowed the "lessee," but "rental"

and that received by it, its income for tax purposes will be the full "rental" paid it by Allied. Repayments of principal to its creditors will, of course, not be deductible from this. See Senate Hearings 557-61 for Union's figures. A large university such as Yale, on the other hand, can expect to be able to pay off all necessary debts, and thus escape the tax completely. C $f$. the remarks of Senator Taft to the representative of Union, id. at 554 ("I am a trustee of Yale University and I would not think of going into such a transaction. I would not conceive of it. I would not for a moment, as trustee, authorize the college to get into such an enterprise of this kind. I do not understand the action of the trustees. There is no immediate income practically, is there?"). Compare letter from L. G. Tighe, Treasurer of Yale University, $i d$. at 586. A recent Yale deal with Macy's in San Francisco was at least partially debt-financed.

56. Cf. Note, Taxation of Intercorporate Assets: An Expanding Loophole, 60 YALE L.J. 140 (1951).

57. Brief mention of the possibility of using this approach can be found in House Hearings $497 ; i d$. at 586.

58. In Helvering v. F. \& R. Lazarus \& Co., 308 U. S. 252 (1939), the court Fermitted petitioner lessee to take depreciation deductions on three store buildings occupied under a 99-year lease-back with an option to renew or purchase. Presumably rental deductions were therefore disallowed. See especially language in $i d$. at 254-5. Cf. Higgins v. Smith, 308 U. S. 473 (1939) (capital loss disallowed on transfer when control retained); Griffiths v. Commissioner, 30 U U. S. 355 (1939). See discussion in Cary, supra note 2 , at $23-7$, and citations there given.

See also Century Electric Co. and Standard Envelope Mfg. Co., supra note 25; Armston v. Commissioner, 12 T.C. 539 (1949). 